\title{
Comparing and combining predictors of mostly disordered
}

proteins:

\section{Supplementary Information}

Christopher J. Oldfield ${ }^{\ddagger,}$, Yugong Cheng ${ }^{\ddagger}$, Mark S. Cortese ${ }^{\ddagger, \#}$, Celeste J. Brown", Vladimir N. Uversky ${ }^{*, \#, \|, *}$ and A. Keith Dunker, ${ }^{i, \#, * *}$

${ }^{\ddagger}$ Molecular Kinetics, Inc. 6201 La Pas Trail, Suite 160, Indianapolis, IN 46268, USA; \# Center for Computational Biology and Bioinformatics, Department of Biochemistry and Molecular Biology, School of Medicine, Indiana University - Purdue University at Indianapolis, Indianapolis, IN 46202; ${ }^{\text {Il }}$ Department of Biological Sciences, University of Idaho, Moscow, Idaho 83844, USA; " Institute for Biological Instrumentation, Russian Academy of Sciences, 142292 Pushchino, Moscow Region, Russia; ${ }^{\S}$ Present Address: Biophysics Department, Institute for Molecular Virology 1525 Linden Drive, Madison, WI 53706 
Receiver Operator Characteristics (ROC) Curves. ROC curves are plots of the true positive rate (e.g., fraction of correct disorder predictions) as a function of the false positive rate (e.g., fraction of incorrect disordered predictions) generated by varying the prediction threshold. Empirical ROC curves have been generated for the prediction methods with discrete outputs, the consensus score and CDF predictions, and kernel density estimation-based ROC curves $(S 1)$ have been generated for charge-hydropathy prediction. Two sets of curves were generated, one using wholly ordered proteins as the negative set (Fig. S1A) and the other using partially ordered proteins as the negative set (Fig. S2A). Both sets of curves use the wholly disordered proteins as the positive set.

A note should be given on the correspondence of this data to the Tables in the text. Tables I and II in the text are not equivalent to Fig S1. The ROC curve values are generated using a sliding threshold, but the values reported in the tables are generated using prediction margins, where only proteins with prediction values falling a certain distance from the boundary are predicted and proteins with prediction values closer to the boundary are not predicted. The data in Table III corresponds to a single point on each of the curves in Fig S1.

Wholly ordered proteins (PDB identification and chain identification, if applicable): 1A0K, 1A3H, 1A8Q, 1AA2, 1AD6, 1AIE, 1AKO, 1AKZ, 1AM5, 1AOV, 1AR2, 1B9K A, 1BD8, 1BEE, 1BFS, 1BG5, 1BK2, 1BLE, 1BM8, 1BU2 A , 1BYW A, 1BZ4 A, 1C25, 1C3G A, 1C44 A, 1C93 A, 1CDZ A, 1CM3 A, 1CQY A, 1CWY A, 1D2K A, 1D2P A, 1DAB A, 1DC9A, 1DT4 A, 1DVO A, 1DYW A, 1EG3 A, 1EH1 A, 1EM7 A, 1EOV A, 1EQ6 A, 1EW4 A, 1EYH A, 1F00 I, 1FNF, 1FSF A, 1FSO A, 1FTS, 1G5Z A, 1 G62 A, 1G9O A, 1GC7 A, 1GXQ A, 1GYV A, 1H6T A, 1HH0 A, 1HH2 P, 1HKA, 1HXU A, 1I2T A, 1I5I A, 1ICX A, 1IFP, 1ILW A, 1IO2 A, 1IS5 A, 1JEJ A, 1JLN A, 1JW4 A, 1K6K A, 1KAS, 1L2P A, 1LA1 A, 1LCL, 1LP3 A, 1LPL A, 1MFO A, 1OPS, 1PBV, 1PZC, 1QAU A, 1QCQ A, 1QQH A, 1QS9 A, 1QTOA, 1SKF, 1SLL, 1TYV, 1UIA, 1UOK, 1VSM A, 1WAL A, 1XGO, 2ALD A, 2ARA, 2BVV A, 2ERA, 2GPR, 2PLC, 2PTH, 2TMY, 6RHN, 8OHM, 9ILB A

Partially ordered proteins (PDB identification and chain identification, if applicable, followed by the range of residues with missing electron density):

1TMO, 1-35; 1D2M A, 159-165, 213-235, 584-665; 1C8D A, 1-36; 1JDW, 1-63; 1DD7 A, 153-156, 214-222, 256-299, 332-364, 385-389; 1GJV A, 1-37, 307-334, 379-388; 1JPH A, 1-30; 1AS0, 1-30, 344-353; 1KMO A, 1-113; 1QME A, 1-22, 46-135, 185-205, 574-584; 2CAU A, 1-45, 224-245, 323-332, 422-445; $1 \mathrm{G} 41$ A, 88-91, 121-225; 1JNK, 1-44, 212-216, 375-379, 401-422; 1A5Y, 286-330; 1QQ0 A, 1-39; 1RGP, 1-35, 206-215, 235-242; 1DAR, 39-66, 401-432, 443-447, 458466, 690-691; 1D6M A, 185-190, 610-653; 1CHU A, 44-56, 104-141, 411-413, 534-540; 1GCY A, 68-70, 419-527; 1HVX A, 484-515; 1DZL A, 1-19, 475-505; 1AK5, 102-221, 315-328, 413-431, 484-503; 1BIF, 1-37; 1RDR, 1-11, 38-66, 98181, 270-290; 1QHU A, 1-48, 124-130, 241-247; 1G9U A, 1-33, 387-454; 1C5K A, 1-34, 432-439; 1F1O A, 1-8, 138-139, 183-188, 255-262, 345-350, 361-395, 417-431; 1FGS, 18-19, 146-150, 170-176, 342-347, 373-384, 426-428; 1 IR6 A, 1-9, 395-424; 2NCD A, 1-22, 308-317, 391-420; 1FKM A, 263-322, 344-346, 
384-396; 1J9Y A, 1-5, 286-293, 323-353, 382-385; 1IIP A, 299-370; 1HZF A, 139, 264-265, 276-299, 366-367; 16VP A, 304-348, 357-366; 1HW4 A, 1-67, 149170, 353-355; 1K6I A, 1-2, 285-316; 1AL3, 1-87; 1BOO A, 1-2, 166-203; 1HNK A, 84-86, 146-152, 185-217, 305-307; 1CJM A, 1-7, 64-77, 91-93, 216-261, 294295; 1I7F A, 1-3, 232-292; 1CBF, 1-12, 252-285; 1LBD, 1-44; 1KKU A, 1-4, 111-147, 258-279; 1DVE A, 1-9, 224-267; 1HYQ A, 234-263; 1B6U, 1-4, 204257; 2TDX, 140-226; 1DMG A, 42-94; 1EH7 A, 1-4, 36-45, 177-207; 1CYX, 114, 173-205; 1FM5 A, 1-83; 1AF3, 31-80; 1HZT A, 1-30, 184-190; 1AMX, 1-30; 1DLY A, 1-43; 1FHG A, 1-33, 136-154; 1AVV, 1-18, 93-123, 149-151; 1MB1, 1-2, 101-130; 1JNI A, 1-36, 87-91, 104-123; 1BB9, 1-32

Wholly disordered proteins (with references):

P06454(S2), P02315(S3), P07746(S3), P10636(S4), O76070(S5), Q13541(S6), P17639(S7), AAC48720(S8), O06022(S9), AAC48700(S8), Q9XZH1(S10), P02387(S1 1), P02375(S11), P02427(S11), P02367(S11), P02374(S11), P02379(S1 1), P02432(S11), P02435(S11), P02436(S11), P02437(S11), P02662(S12), P04324(S13), P19103(S14), P12272(S15), P02687(S16), P38936(S17), P22239(S18), P10622(S19, 20, 21), P03045(S22, 23), P00006(S24), P04554(S25), P81455(S26), AAF13399(S27), P43532(S28), P04541(S29), P35326(S30), P01050(S31), P15340(S32), P02845(S33), P32499(S34), P21815(S35), P10451(S35), P19429(S36), P13795(S37, 38), Q9Z2E4(S39), P16949(S40), P03671(S41), P17096(S42, 43, 44), 2SOB(S45), P62803(S46), Q62100(S47), Q13956(S48), P42692(S49),

\section{FIGURE LEGENDS}

Figure S1. ROC curves for the consensus score (red line), CDF predictions (blue line), and charge-hydropathy prediction (black line). Marked points on the lines of the consensus score and CDF predictions correspond to the discrete prediction thresholds and only these points are meaningful. Charge-hydropathy predictions are continuous, so the entire line is meaningful. ROC curves where generated using the wholly disordered proteins as a positive set and either (A) the wholly ordered proteins or (B) the partially ordered proteins as a negative set.

\section{REFERENCES}

S1. Zou, K. H., Hall, W. J., and Shapiro, D. E. (1997) Smooth non-parametric receiver operating characteristic (ROC) curves for continuous diagnostic tests, Statistics in Medicine 16, 2143-2156.

S2. $\quad$ Gast, K., Damaschun, H., Eckert, K., Schulze-Forster, K., Maurer, H. R., MullerFrohne, M., Zirwer, D., Czarnecki, J., and Damaschun, G. (1995) Prothymosin alpha: a biologically active protein with random coil conformation, Biochemistry 34, 13211-13218. 
S3. Cary, P. D., Crane-Robinson, C., Bradbury, E. M., and Dixon, G. H. (1981)

Structural studies of the non-histone chromosomal proteins HMG-T and H6 from trout testis, Eur. J. Biochem. 119, 545-551.

S4. Schweers, O., Schoenbrunn-Hanebeck, E., Marx, A., and Mandelkow, E. (1994) Structural Studies of Tau Protein and Alzheimer Paired Helical Filaments Show No Evidence for $\beta$-Structure, J. Bio. Chem. 269, $24290-24297$.

S5. Weinreb, P. H., Zhen, W., Poon, A. W., Conway, K. A., and Lansbury, P. T., Jr. (1996) NACP, a protein implicated in Alzheimer's disease and learning, is natively unfolded, Biochemistry 35, 13709-13715.

S6. Fletcher, C. M., McGuire, A. M., Gingras, A. C., Li, H., Matsuo, H., Sonenberg, N., and Wagner, G. (1998) 4E binding proteins inhibit the translation factor eIF4E without folded structure, Biochemistry 37, 9-15.

S7. Eom, J., Baker, W., Kintanar, A., and Wurtele, E. (1996) The embryo-specific EMB-1 protein of Daucus carota is flexible and unstructed in solution., Plant Sci. $115,17-24$.

S8. Yoo, S. H., and Albanesi, J. P. (1990) Ca2(+)-induced conformational change and aggregation of chromogranin A, J. Biol. Chem. 265, 14414-14421.

S9. Larsen, R. W., Yang, J., Hou, S., Helms, M. K., Jameson, D. M., and Alam, M. (1999) Spectroscopic characterization of two soluble transducers from the Archaeon Halobacterium salinarum, J Protein Chem 18, 269-75.

S10. Lynn, A., Chandra, S., Malhotra, P., and Chauhan, V. S. (1999) Heme binding and polymerization by Plasmodium falciparum histidine rich protein II: influence of $\mathrm{pH}$ on activity and conformation, FEBS Lett 459, 267-71.

S11. Venyaminov, S., Gudkov, A., Gogia, Z., and Tumanova, L. (1981) pp 128, Biological Research Center, Institute of Protein Research, Pushchino: AS USSR.

S12. Bhattacharyya, J., and Das, K. P. (1999) Molecular chaperone-like properties of an unfolded protein, alpha(s)- casein, J. Biol. Chem. 274, 15505-15509.

S13. Geyer, M., Munte, C. E., Schorr, J., Kellner, R., and Kalbitzer, H. R. (1999) Structure of the anchor-domain of myristoylated and non-myristoylated HIV-1 Nef protein, J. Mol. Biol. 289, 123-138.

S14. Nimmo, G. A., and Cohen, P. (1978) The regulation of glycogen metabolism. Purification and characterisation of protein phosphatase inhibitor-1 from rabbit skeletal muscle, Eur. J. Biochem. 87, 341-351.

S15. Willis, K. J. (1994) Interaction with model membrane systems induces secondary structure in amino-terminal fragments of parathyroid hormone related protein, Int. J. Pept. Protein Res. 43, 23-28.

S16. Polverini, E., Fasano, A., Zito, F., Riccio, P., and Cavatorta, P. (1999) Conformation of bovine myelin basic protein purified with bound lipids, Eur Biophys J 28, 351-5.

S17. Kriwacki, R. W., Hengst, L., Tennant, L., Reed, S. I., and Wright, P. E. (1996) Structural studies of $\mathrm{p} 21^{\text {Wafl/Cip1/Sdil }}$ in the free and Cdk2-bound state: conformational disorder mediates binding diversity, Proc. Natl. Acad. Sci. USA 93, 11504-11509.

S18. Lisse, T., Bartels, D., Kalbitzer, H. R., and Jaenicke, R. (1996) The recombinant dehydrin-like desiccation stress protein from the resurrection plant Craterostigma 
plantagineum displays no defined three- dimensional structure in its native state, Biol Chem 377, 555-61.

S19. Zurdo, J., Gonzalez, C., Sanz, J. M., Rico, M., Remacha, M., and Ballesta, J. P. (2000) Structural differences between Saccharomyces cerevisiae ribosomal stalk proteins P1 and P2 support their functional diversity, Biochemistry 39, 89358943.

S20. Nusspaumer, G., Remacha, M., and Ballesta, J. P. (2000) Phosphorylation and Nterminal region of yeast ribosomal protein $\mathrm{P} 1$ mediate its degradation, which is prevented by protein P2, Embo J 19, 6075-6084.

S21. Zurdo, J., Sanz, J. M., Gonzalez, C., Rico, M., and Ballesta, J. P. (1997) The exchangeable yeast ribosomal acidic protein YP2beta shows characteristics of a partly folded state under physiological conditions, Biochemistry 36, 9625-9635.

S22. Legault, P., Li, L., Mogridge, J., Kay, L. E., and Greenblatt, J. (1998) NMR Structure of the Bacteriophage lambda N Peptide/box B RNA Complex:

Recognition of a GNRA Fold by an Arginine-Rich Motif, Cell 93, 289-299.

S23. Mogridge, J., Legault, P., Li, J., Van Oene, M. D., Kay, L. E., and Greenblatt, J. (1998) Independent ligand-induced folding of the RNA-binding domain and two functionally distinct antitermination regions in the phage lambda $\mathrm{N}$ protein, Mol. Cell 1, 265-275.

S24. Stellwagen, E., Rysavy, R., and Babul, G. (1972) The conformation of horse heart apocytochrome c*, J Biol Chem 247, 8074-7.

S25. Gatewood, J. M., Schroth, G. P., Schmid, C. W., and Bradbury, E. M. (1990) Zinc-induced secondary structure transitions in human sperm protamines, J. Biol. Chem. 265, 20667-20672.

S26. Isbell, D. T., Du, S., Schroering, A. G., Colombo, G., and Shelling, J. G. (1993)

Metal ion binding to dog osteocalcin studied by 1H NMR spectroscopy, Biochemistry 32, 11352-11362.

S27. Pahel, G., Aulabaugh, A., Short, S. A., Barnes, J. A., Painter, G. R., Ray, P., and Phelps, W. C. (1993) Structural and functional characterization of the HPV16 E7 protein expressed in bacteria, J Biol Chem 268, 26018-25.

S28. Daughdrill, G. W., Hanely, L. J., and Dahlquist, F. W. (1998) The C-terminal half of the anti-sigma factor FlgM contains a dynamic equilibrium solution structure favoring helical conformations, Biochemistry 37, 1076-1082.

S29. Thomas, J., Van Patten, S. M., Howard, P., Day, K. H., Mitchell, R. D., Sosnick, T., Trewhella, J., Walsh, D. A., and Maurer, R. A. (1991) Expression in Escherichia coli and characterization of the heat-stable inhibitor of the cAMPdependent protein kinase, J Biol Chem 266, 10906-11.

S30. Tarcsa, E., Candi, E., Kartasova, T., Idler, W. W., Marekov, L. N., and Steinert, P. M. (1998) Structural and transglutaminase substrate properties of the small proline-rich 2 family of cornified cell envelope proteins, J Biol Chem 273, 23297303.

S31. Otto, A., and Seckler, R. (1991) Characterization, stability and refolding of recombinant hirudin, Eur J Biochem 202, 67-73.

S32. Nakano, M., Kasai, K., Yoshida, K., Tanimoto, T., Tamaki, Y., and Tobita, T. (1989) Conformation of the fowl protamine, galline, and its binding properties to DNA, J Biochem (Tokyo) 105, 133-7. 
S33. Ptitsyn, O. (1995) Molten globule and protein folding, Adv. Protein Chem. 47, 83229.

S34. Denning, D. P., Uversky, V., Patel, S. S., Fink, A. L., and Rexach, M. (2002) The Saccharomyces cerevisiae nucleoporin Nup2p is a natively unfolded protein, $J$ Biol Chem 277, 33447-55.

S35. Fisher, L. W., Torchia, D. A., Fohr, B., Young, M. F., and Fedarko, N. S. (2001) Flexible structures of SIBLING proteins, bone sialoprotein, and osteopontin, Biochem Biophys Res Commun 280, 460-5.

S36. Ferrieres, G., Calzolari, C., Mani, J. C., Laune, D., Trinquier, S., Laprade, M., Larue, C., Pau, B., and Granier, C. (1998) Human cardiac troponin I: precise identification of antigenic epitopes and prediction of secondary structure, Clin. Chem. 44, 487-493.

S37. Fasshauer, D., Otto, H., Eliason, W. K., Jahn, R., and Brunger, A. T. (1997) Structural changes are associated with soluble N-ethylmaleimide-sensitive fusion protein attachment protein receptor complex formation, J. Biol. Chem. 272, 28036-28041.

S38. Fasshauer, D., Bruns, D., Shen, B., Jahn, R., and Brunger, A. T. (1997) A structural change occurs upon binding of syntaxin to SNAP-25, J. Biol. Chem. $272,4582-4590$.

S39. Aswad, D. W., and Greengard, P. (1981) A specific substrate from rabbit cerebellum for guanosine 3':5'- monophosphate-dependent protein kinase. II. Kinetic studies on its phosphorylation by guanosine $3^{\prime}: 5^{\prime}$-monophosphatedependent and adenosine 3':5'-monophosphate-dependent protein kinases, J. Biol. Chem. 256, 3494-3500.

S40. Belmont, L. D., and Mitchison, T. J. (1996) Identification of a protein that interacts with tubulin dimers and increases the catastrophe rate of microtubules, Cell 84, 623-631.

S41. Bogdarina, I., Fox, D. G., and Kneale, G. G. (1998) Equilibrium and kinetic binding analysis of the N-terminal domain of the Pf1 gene 5 protein and its interaction with single-stranded DNA, J. Mol. Biol. 275, 443-452.

S42. Huth, J. R., Bewley, C. A., Nissen, M. S., Evans, J. N., Reeves, R., Gronenborn, A. M., and Clore, G. M. (1997) The solution structure of an HMG-I(Y)-DNA complex defines a new architectural minor groove binding motif, Nat. Struct. Biol. 4, 657-665.

S43. Pierantoni, G. M., Fedele, M., Pentimalli, F., Benvenuto, G., Pero, R., Viglietto, G., Santoro, M., Chiariotti, L., and Fusco, A. (2001) High mobility group I (Y) proteins bind HIPK2, a serine-threonine kinase protein which inhibits cell growth, Oncogene 20, 6132-41.

S44. Munshi, N., Agalioti, T., Lomvardas, S., Merika, M., Chen, G., and Thanos, D. (2001) Coordination of a transcriptional switch by HMGI(Y) acetylation, Science 293, 1133-6.

S45. Alexandrescu, A. T., Abeygunawardana, C., and Shortle, D. (1994) Structure and dynamics of a denatured 131-residue fragment of staphylococcal nuclease: a heteronuclear NMR study, Biochemistry 33, 1063-1072. 
S46. Munishkina, L. A., Fink, A. L., and Uversky, V. N. (2004) Conformational prerequisites for formation of amyloid fibrils from histones, J Mol Biol 342, 130524.

S47. Warrant, R. W., and Kim, S. H. (1978) alpha-Helix-double helix interaction shown in the structure of a protamine-transfer RNA complex and a nucleoprotamine model, Nature 271, 130-135.

S48. Uversky, V. N., Permyakov, S. E., Zagranichny, V. E., Rodionov, I. L., Fink, A. L., Cherskaya, A. M., Wasserman, L. A., and Permyakov, E. A. (2002) Effect of zinc and temperature on the conformation of the gamma subunit of retinal phosphodiesterase: a natively unfolded protein, J Proteome Res 1, 149-59.

S49. Needham, G. F., Pekar, A. H., and Havel, H. A. (1995) Effect of salts on the structure of a potent analog of growth hormone releasing hormone as determined by optical spectroscopy, J Pharm Sci 84, 437-442. 
Figure S1.

A

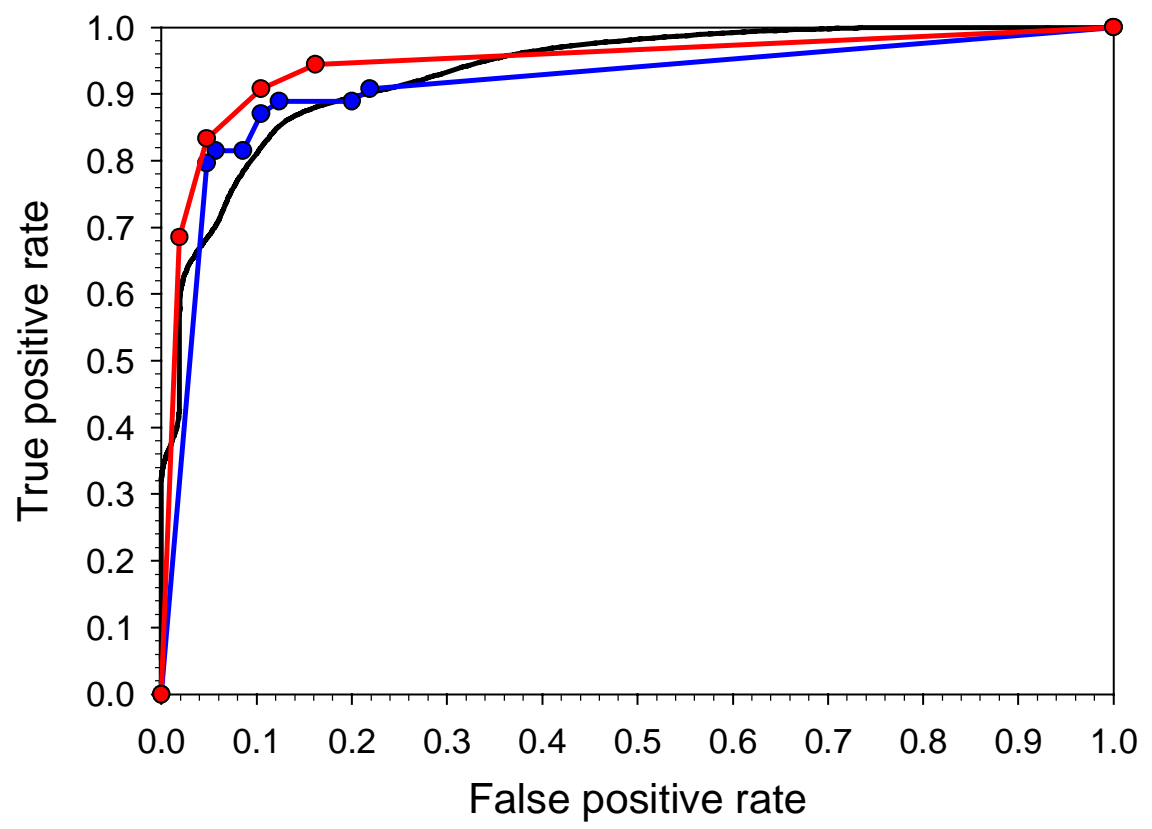

B

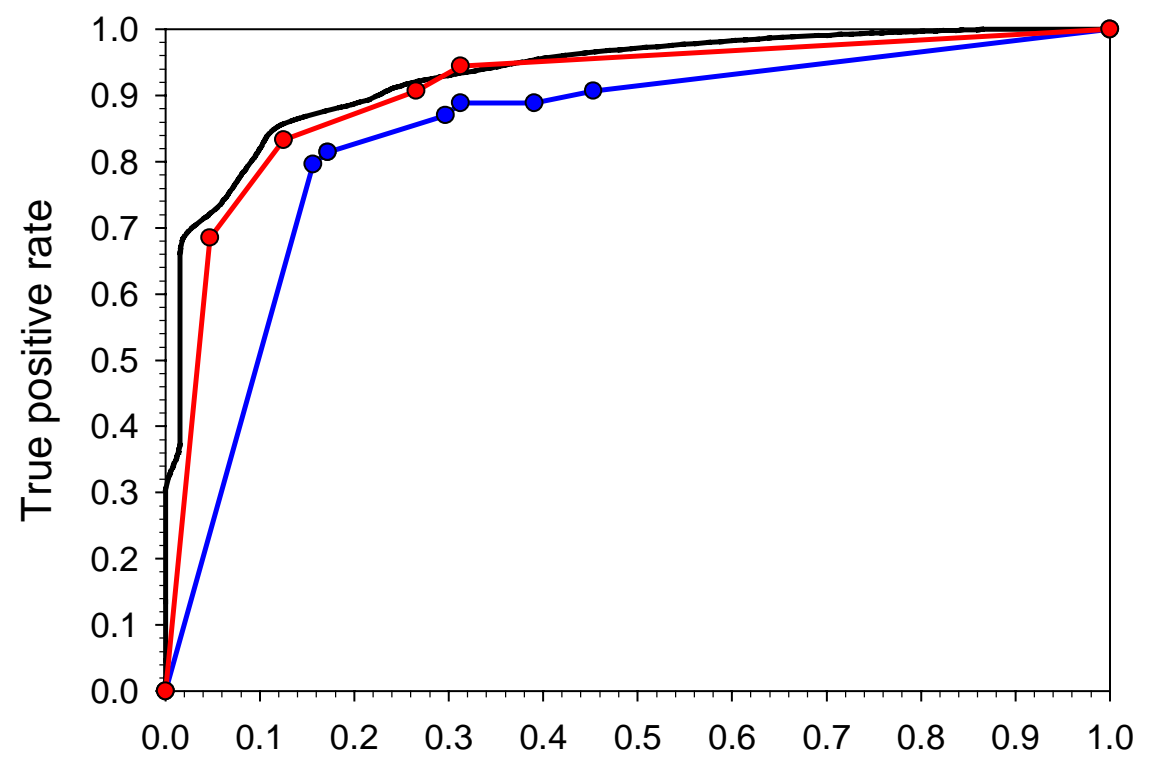

False positive rate 